\title{
PENGARUH PENGGUNAAN MEDIA PEMBELAJARAN BERBASIS KOMPUTER TERHADAP MOTIVASI DAN KETERAMPILAN KOMPUTER SISWA DALAM BELAJAR MATEMATIKA
}

\author{
Dita Agustiani $^{\mathrm{a}}$, Toheri ${ }^{\mathrm{b}}$, Darwan $^{\mathrm{c}}$ \\ a Jurusan Tadris Matematika IAIN Syekh Nurjati Cirebon \\ Jl. Perjuangan Bypass Sunyaragi Cirebon, ditaagustiani@syekhnurjati.ac.id \\ b Jurusan Tadris Matematika IAIN Syekh Nurjati Cirebon \\ Jl. Perjuangan Bypass Sunyaragi Cirebon, toheri@ syekhnurjati.ac.id \\ ${ }^{c}$ Jurusan Tadris Matematika IAIN Syekh Nurjati Cirebon \\ Jl. Perjuangan Bypass Sunyaragi Cirebon, darwan@ syekhnurjati.ac.id
}

\begin{abstract}
Abstrak
Rendahnya motivasi belajar dan keterampilan komputer siswa dalam pembelajaran matematika salah satunya disebabkan karena penerapan media pembelajaran yang masih jarang, sehingga perlu diadakan pemanfaatan media secara optimal. Komputer merupakan salah satu media pembelajaran dalam matematika yang dapat digunakan untuk penelitian ini. Tujuan diadakannya penelitian ini adalah untuk melihat pengaruh penggunaan media pembelajaran berbasis komputer terhadap motivasi dan keterampilan komputer siswa. Penelitian ini merupakan studi eksperimen di SMAN 1 Astanajapura melalui desain One-Shot Case Study dengan sampel berjumlah 32 siswa dan teknik pengumpulan data dilakukan dengan instrument tes angket dan observasi. Hasil penelitian menunjukan bahwa: (1) respon siswa terhadap penggunaan media komputer masuk dalam kategori cukup baik dengan nilai prosentase sebesar 70,34\%, (2) motivasi belajar siswa dalam belajar matematika masuk dalam kategori cukup baik dengan nilai prosentase sebesar $74,77 \%$, (3) keterampilan komputer siswa dalam belajar matematika masuk dalam kategori baik dengan nilai prosentse sebesar 73,06\%, (4) hasil uji hipotesis dengan menggunakan uji t antara variabel $X$ dengan $Y_{1}$ diperoleh nilai signifikansi lebih kecil dari 0,05 yaitu sebesar 0,000 sehingga $\mathrm{H}_{0}$ ditolak artinya terdapat pengaruh antara penggunaan media pembelajaran berbasis komputer terhadap motivasi belajar siswa, antara variabel $\mathrm{X}$ dengan $\mathrm{Y}_{2}$ diperoleh nilai signifikansi lebih kecil dari 0,05 yaitu sebesar 0,045 sehingga $\mathrm{H}_{0}$ ditolak artinya terdapat pengaruh antara penggunaan media pembelajaran berbasis komputer terhadap keterampilan komputer siswa, antara variabel $\mathrm{Y}_{1}$ dengan $\mathrm{Y}_{2}$ diperoleh nilai signifikani lebih besar dari 0,05 yaitu sebesar 0,511 sehingga $\mathrm{H}_{0}$ diterima artinya tidak terdapat pengaruh antara motivasi belajar siswa terhadap keterampilan komputer siswa.Berdasakan hasil penelitian ini, peneliti memberikan saran bahwa perlu diadakannya pendidikan karakter yang dapat membangkitkan motivasi belajar siswa serta perlu inovasi dalam belajar melalui pemanfaatan komputer sebagai media pembelajaran, sehingga siswa mampu meningkatkan motivasi belajar dan keterampilan dalam menggunakan komputer.
\end{abstract}

Kata Kunci : Media pembelajaran berbasis komputer (software maple), motivasi belajar siswa, keterampilan komputer siswa.

\begin{abstract}
One of students low motivation and computer skills in learning mathematics is caused by application of learning media which is still rare, with the result that the media need to be used optimally. Computer is one of learning media in mathematics used for this research. The aim of the research is to see the influence of using computer-based learning media towards students' learning motivation and computer skills. This research used the experimental method in SMAN 1 Astanajapura by One-Shot Case Study design with 32 samples and technique of data collection used observation and questionnaires. The result of this research showed that: (1) Students' responses toward using computer was in good enough category with a percentage of $70,34 \%$, (2) Students' learning motivation in learning mathematics was in good enough category with a percentage of $74,77 \%$, (3) Students' computer skillsin learning mathematics was in good category with a percentage of $73,06 \%$, (4) The result of hypothesis test using the $\mathrm{T}$ test between $\mathrm{X}$ and $\mathrm{Y}_{2}$
\end{abstract}


variable was got significant value smaller than 0.05 , that was 0.000 so that $\mathrm{H}_{0}$ was rejected meant there was influence between the use of computer-based learning media towards students' computer skills, between $Y_{1}$ and $Y_{2}$ was acquired the significant value greater than 0.05 , that was 0.511 so that $\mathrm{H}_{0}$ was received meant there was nothing influence between students' learning motivation toward students' computer skills. Based on the result of the research, the researcher gave suggestions that is necessary to use character education for improving students' learning motivation and inovation in learning by using computer as learning media, with the result that students are able to increase learning motivation and computer skill in applying it.

Keyword: Computer-based learning media (software Maple), students' learning motivation, Students' computer skills.

\section{PENDAHULUAN}

Keberhasilan sistem pendidikan bertumpu pada keberhasilan proses belajar dan mengajar yang dilakukan oleh seorang pendidik dan peserta didiknya di sekolah. Salah satu masalah yang dihadapi dalam dunia pendidikan di Indonesia adalah lemahnya proses pembelajaran. Banyak kita jumpai, siswa tidak tertarik mempelajari suatu pelajaran karena materi pelajaran tersebut cukup sulit untuk dipahami. Untuk menghindari gejala tersebut, guru harus memilih dan mengorganisasi materi pelajaran tersebut sedemikian rupa, sehingga merangsang dan menentang siswa untuk mengerjakannya. Menurut (Kustandi \& Sujipto, 2016) kemampuan profesional guru dituntut agar: (1) kreatif dalam menyajikan pelajaran yang merangsang dan menantang, (2) dapat menumbuhkan motivasi belajar siswa, (3) memberikan penguatan atau reinforcement suatu tindakan yang perlu dilakukan serta pemberian balikan. Berdasarkan pendapat ahli dapat disimpulkan bahwa untuk menjadi guru profesional tidak hanya melakukan proses belajar mengajar materi pembelajaran di kelas, namun harus mampu menyajikan pelajaran yang kreatif, inovatif, serta harus mampu menumbuhkan motivasi siswa agar siswa lebih giat dalam melakukan proses pembelajaran.

Motivasi belajar dalam proses pembelajaran matematika sangat diperlukan dan guru harus senantiasa memberikan motivasi-motivasi dalam setiap proses pembelajaran karna itu sangat berguna dalam keberhasilan proses pembelajaran yang dilakukan. Adapun indikator motivasi belajar dapat diklasifikasikan sebagai berikut: (1) adanya hasrat dan keinginan berhasil, (2) adanya dorongan dan kebutuhan dalam belajar, (3) adanya harapan dan cita-cita masa depan, (4) adanya penghargaan dalam belajar, (5) adanya kegiatan yang menarik dalam belajar, (6) adanya lingkungan belajar yang kondusif, sehingga memungkinkan seseorang siswa dapat belajar dengan baik (Uno, 2008). 
Namun demikian, hal tersebut bertentangan dengan apa yang terjadi di lapangan yaitu motivasi belajar matematika siswa rendah. Berdasarkan hasil temuan penulis pada saat PPL 2 terlihat bahwa motivasi siswa dalam belajar matematika masih kurang. Seringkali siswa beralasan pergi ke kamar mandi yang pada kenyataanya mereka malah tidak mengikuti mata pelajaran matematika sampai waktu pembelajaran berakhir. Motivasi siswa salah satunya dipengaruhi oleh minat siswa terhadap mata pelajaran. Siswa yang memiliki minat terhadap sesuatu cenderung akan memberikan perhatian lebih dan mempelajarinya dengan sepenuh hati.

Untuk mengatasi masalah tersebut, salah satu upaya yang dapat dilakukan oleh guru yaitu dengan mendesain pembelajaran menjadi lebih menarik dan siswa menjadi lebih termotivasi untuk belajar lebih baik. Salah satu alternatifnya yaitu dengan melakukan inovasi baru yaitu penggunaan media pembelajaran interaktif. Hamalik dalam (Arsyad, 2013) mengemukakan bahwa pemakaian media pembelajaran dalam proses belajar mengajar dapat membangkitkan keinginan dan minat yang baru, membangkitkan motivasi dan rangsangan kegiatan belajar. Salah satu penggunaan media interaktif dalam pembelajaran matematika yaitu dengan penggunaan media pembelajaran berbasis komputer. Menurut (Arsyad, 2013) menyatakan bahwa komputer dapat mengakomodasikan siswa yang lamban menerima pelajaran, karena ia dapat memberikan iklim yang lebih bersifat efektif dengan cara lebih individual, tidak pernah lupa, tidak pernah bosan, sangat sabar dalam menjalankan intruksi seperti yang diinginkan program yang digunakan.

Untuk menunjang pembelajaran berbasis komputer tentunya dibutuhkan sarana dan prasarana yang memadai. Berdasarkan hasil temuan penulis di SMAN Astanajapura bahwa sarana dan prasarana di sekolah tersebut cukup lengkap, salah satunya media komputer. Dengan adanya fasilitas yang cukup memadai tentunya akan mempermudah guru dalam penggunaan media pembelajaran berbasis komputer. Namun demikian, melihat kenyataan di lapangan yaitu di SMAN 1 Astanajapura jarang sekali guru matematika memanfaatkan media komputer sebagai media pembelajaran matematika, bahkan sebagian besar dari mereka tidak menggunakannya sebagai media pembelajaran.

Dalam proses pembelajaran menggunakan media berbasis komputer 
tentunya membutuhkan keterampilan siswa. Keterampilan lahir dari proses belajar dan merupakan suatu tindakan siswa untuk memenuhi segala potesinya yang menyangkut kebutuhan kognitif dan efektif. Namun demikian, fakta yang didapat oleh penulis di lapangan siswa masih kurang terampil dalam belajar matematika. Hal tersebut dipengaruhi oleh sistem pembelajaran yang digunakan di sekolah terutama dalam penggunaan komputer sebagai media pembelajaran. Siswa cenderung memiliki kemampuan yang kurang ahli dalam menggunakan komputer sebagai media pembelajaran dikarenakan guru di sekolah tersebut jarang memanfaatkannya.

Berdasarkan uraian tersebut alternatif solusinya yaitu dengan memanfaatkan media komputer sebagai media pembelajaran matematika. Penulis mengangkat masalah: Pengaruh Penggunaan Media Pembelajaran Berbasis Komputer terhadap Motivasi Belajar dan Keterampilan Komputer Siswa.

\section{METODE PENELITIAN}

Jenis penelitian ini menggunakan jenis eksperimen dengan pendekatan kuantitatif (Sugiyono, 2018). Desain penelitian ini, desain yang digunakan adalah One-Shot Case Study yaitu rancangan yang hanya diterapkan pada satu kelompok untuk diberi perlakuan dan selanjutnya diobservasi hasilnya (Suharsaputra, 2012). Populasi adalah kelompok besar dan wilayah yang menjadi lingkup penelitian (Sukmadinata, 2016) .Populasi target dalam penelitian ini adalah seluruh siswa kelas XI semester genap di SMAN 1 Astanajapura tahun ajaran 2018/ 2019. Pengambilan sampel menggunakan teknik simple random sampling sederhana satu stage, maka pemilihan sampelnya diambil secara acak karena dari lima kelas dianggap homogen. Setelah melakukan pengacakan, peneliti mendapatkan satu kelas buat sample penelian yaitu kelas XI MIA 5. Instrumen yang digunakan dalam penelitian ini menggunakan angket dan observasi. Adapun kerangka pikir dalam penelitian ini seperti ditunjukkan pada Gambar 1.

Berdasarkan penelitian yang dilakukan oleh Gufron, Darwan, \& Winarso (2018) dengan judul Penggunaan Bahan Ajar Berbasis Multimedia Interaktif terhadap Hasil Belajar Matematika Siswa menyatakan bahwa terdapat pengaruh penggunaan multimedia interaktif terhadap aspek belajar matematika siswa yaitu pada ranah afektif, kognitif, dan psikomotorik; Zahro (2017) dengan judul penelitian Perbandingan Penerapan Metode Problem Based Intruction dan Two Stay Stray terhadap Motivasi Belajar 
Matematika menyatakan bahwa motivasi belajar matematika siswa dapat meningkat dengan menggunakan metode problem based intruction dan two stay stray dan tidak ada perbedaan diantara penggunaan keduanya; Pradnyawati (2014) dengan judul Pengaruh Strategi Blended Learning dalam Pembelajaran Kooperatif terhadap Motivasi Belajar Matematika Ditinjau dari Gaya Belajar Siswa di SMP K 2 Harapan menyatakan bahwa motivasi belajar matematika dapat meningkat dengan adanya penggunaan strategi blended learning dalam pembelajaran matematika; Wanipah (2014) dengan judul Pengaruh Penggunaan Media Pembelajaran Berbasis Teknologi Informasi (TI) Software Micrososft Mathematis terhadap Motivasi Belajar Siswa pada Pokok Bahasan Turunan (Differensial) Kelas XI SMAN I Sliyeg menyatakan bahwa penggunaan media pembelajaran berbantuan software Microsoft mathematics berpengaruh terhadap motivasi bel;ajar matemematika siswa; Nugroho (2013) dengan judul Eksperimentasi Penggunaan Media Komputer dalam Pembelajaran Matematika pada Pokok Bahasan Logaritma Ditinjau dari Motivasi Belajar Siswa Kelas X SMA Kota Surakarta menyatakan bahwa tidak terdapat interaksi antar media pembelajaran dan motivasi belajar siswa terhadap prestasi belajar siswa; Semadiartha (2012) dengan judul Pengembangan Media Pembelajaran Berbasis Komputer dengan Microsoft Excel yang Berorientasi Teori Van Hiele pada Bahasan Trigonometri Kelas X SMA untuk Meningkatkan Prestasi dan Motivasi Belajar Matematika Siswa menyatakan bahwa pengembangan media pembelajaran berbasis komputer dengan microsoft excel yang berorientasi teori van hiele meningkatkan prestasi dan motivasi belajar matematika siswa; Widyaningrum (2013) dengan judul Pengaruh Media Pembelajaran Geogebra terhadap Motivasi dan Hasil Belajar Siswa pada Materi Grafik Fungsi Kuadrat di Kelas X SMA Negeri 2 Yogyakarta Tahun Pelajaran 2012/2013 menyatakan bahwa motivasi belajar siswa kelas eksperimen yang menggunakna Geogebra lebih tinggi dibandingkan siswa di kelas kontrol yang tidak menggunakan Geogebra; Syahrir (2012) dengan judul Pengaruh Pembelajaran Kooperatif Tipe Jigsaw dan Teams Game Turnament (TGT) terhadap Motivasi Belajar dan Keterampilan Matematika Siswa SMP (Studi Eksperimen di SMP Darul Hikmah Mataram menyatakan bahwa metode pembelajaran kooperatif tipe jigsaw lebih efektif dibanding metode pembelajaran kooperatif tipe TGT terhadap keterampilan matematika 
siswa SMP. Adapun yang membedakan antara penelitian tersebut dengan yang dilakukan oleh peneliti terdapat pada

Tabel 1 .

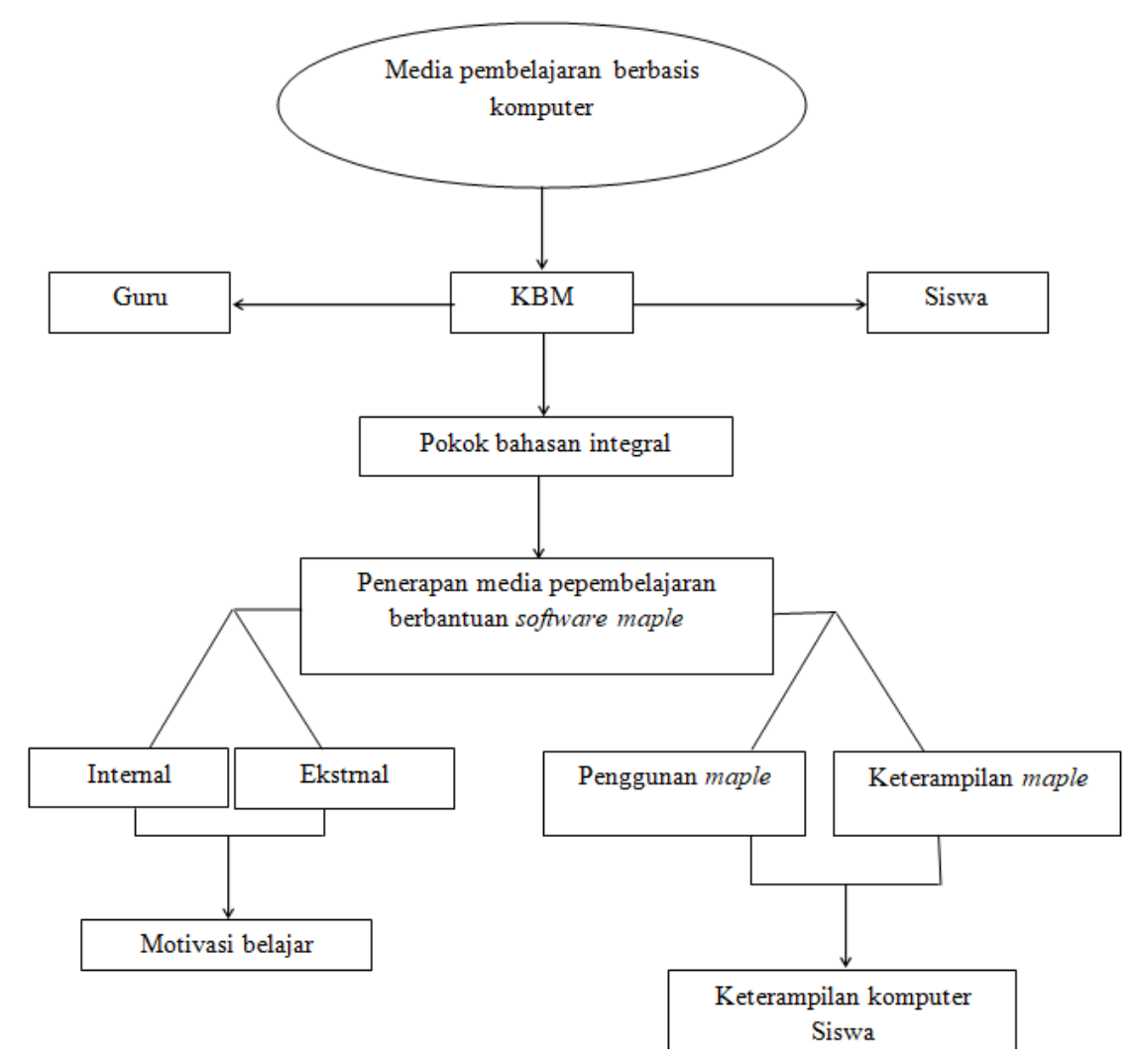

Gambar 1. Kerangka Pikir Penggunaan Media Pembelajaran Berbasis Komputer dalam Pembelajaran

Tabel 1.

\begin{tabular}{|c|l|c|c|c|c|c|c|c|c|c|}
\hline \multirow{2}{*}{ No Nama } & \multicolumn{1}{|c|}{} & \multicolumn{7}{|c|}{ Variabel } & \\
\cline { 3 - 11 } & & A & B & C & D & E & F & G & H & I \\
\hline 1. & Ahmad Gufron (2018) & - & - & - & - & - & - & - & - & $\sqrt{ }$ \\
\hline 2. & Fatimatu Zahro (2017) & - & - & - & - & $\sqrt{ }$ & - & - & - & - \\
\hline 3. & Ludhe Iri Pradnyawati (2014) & - & - & - & - & $\sqrt{ }$ & - & - & - & - \\
\hline 4. & Wanipah (2014) & - & - & - & - & $\sqrt{ }$ & $\sqrt{ }$ & - & - & - \\
\hline 5. & Arif Ganda Nugroho (2013) & $\sqrt{ }$ & - & - & - & - & - & - & - & - \\
\hline 6. & Yulia Tri Widyaningrum (2013) & - & - & $\sqrt{ }$ & - & - & - & $\sqrt{ }$ & - & - \\
\hline 7. & Ikadek Sembah Semadiartha (2012) & - & - & - & $\sqrt{ }$ & - & - & - & - & - \\
\hline 8. & Syahrir (2012) & - & - & - & - & $\sqrt{ }$ & - & - & $\sqrt{ }$ & - \\
\hline 9. & Dita Agustiani (2019) & - & $\sqrt{ }$ & - & - & $\sqrt{ }$ & - & - & $\sqrt{ }$ & - \\
\hline
\end{tabular}

Keterangan:

A : Media Pembelajaran Berbasis Teknologi Informasi Berbantuan Software Macrmedia Flash 8

B : Media Pembelajaran Berbasis Teknologi Informasi Berbantuan Software Maple

C : Media Pembelajaran Berbasis Teknologi Informasi Berbantuan Software Geogebra

D : Media Pembelajaran Berbasis Teknologi Informasi Berbantuan Software Microsoft Excel

E : Motivasi Belajar Matematika

F : Media Pembelajaran Berbasis Teknologi Informasi Berbantuan Software Microsoft Mathematics

G : Hasil Belajar Siswa

$\mathrm{H} \quad$ : Keterampilan belajar siswa

I $\quad$ : Bahan ajar berbasis multimedia interaktif 


\section{HASIL DAN PEMBAHASAN}

\section{A. Deskripsi Hasil Tes}

Dalam penelitian ini, peneliti mengambil sampel hanya satu kelas yaitu siswa kelas XI MIA 5 SMAN 1 Astanajapura yang berjumlah 32 siswa. Dalam melakukan eksperimen peneliti melakukan penyebaran angket sebanyak 25 butir untuk angket respon siswa terhadap penggunaan media pembelajaran berbasis komputer berbantuan software maple, 25 butir untuk angket motivasi belajar matematika, dan memberikan tes untuk mengetahui keterampilan komputer siswa setelah pembelajaran dengan menggunakan media berbasis komputer.

\section{Penggunaan Media Pembelajaran}

\section{Berbasis Komputer Berbantuan}

\section{Software Maple}

Nilai rata-rata yang diperoleh dari angket respon siswa terhadap penggunaan media pembelajaran berbasis komputer berbantuan software maple pada siswa kelas XI SMAN 1 Astanajapura sebesar 70,43\%. Skor tersebut tergolong ke dalam kategori "Cukup Baik" karena berdasarkan tabel skala prosentase nilai $70,43 \%$ berada diantara $65 \%-75 \%$. Jadi dapat disimpulkan bahwa media pembelajaran berbasis komputer merupakan salah satu media yang dapat digunakan oleh guru dalam pembelajaran matematika karna mudah untuk digunakan dalam media pembelajaran, memberikan bantuan belajar matematika siswa, dan membuat siswa lebih tertarik dalam belajar matematika. Berikut merupakan tabel hasil rekapitulasi angket respon siswa:

Tabel 1. Rekapitulasi Angket Respon Siswa terhadap Penggunaan Media Pembelajaran Berbasis Komputer

\begin{tabular}{llc}
\hline No. & \multicolumn{1}{c}{ Indikator } & Kategori (\%) \\
\hline 1. & $\begin{array}{l}\text { Kemudahan } \\
\text { komputer sebagai } \\
\text { media } \\
\text { pembelajaran }\end{array}$ & 66,04 \\
\hline 2. & $\begin{array}{l}\text { Kemudahan dalam } \\
\text { penggunaan } \\
\text { software maple }\end{array}$ & 67,82 \\
\hline & $\begin{array}{l}\text { Memberikan } \\
\text { bantuan belajar dan } \\
\text { rasa ingin tahu } \\
\text { terhadap } \\
\text { pembelajaran } \\
\text { matematika dengan } \\
\text { menggunakan } \\
\text { media } \\
\text { pembelajaran }\end{array}$ \\
\hline & $\begin{array}{l}\text { Ketertarikan dan } \\
\text { perhatian siswa } \\
\text { terhadap } \\
\text { penggunaan media } \\
\text { pembelajaran }\end{array}$ \\
\hline & 71,48 \\
\hline Rata-rata & 76,38 \\
\hline
\end{tabular}

\section{Motivasi Belajar Matematika Siswa}

Nilai rata-rata dari angket motivasi $\begin{array}{lllll}\text { belajar siswa kelas XI SMAN } 1 & \end{array}$ Astanajapura sebesar $68,48 \%$. Skor tersebut tergolong ke dalam kategori "Cukup Baik" karena berdasarkan tabel skala prosentase nilai $74,77 \%$ berada diantara $55 \%-75 \%$. Jadi dapat disimpulkan bahwa hasil angket motivasi belajar siswa menunjukan bahwa 
penggunaan media pembelajaran berbasis komputer dapat meningkatkan motivasi belajar siswa. Berikut merupakan tabel tekapitulasi angket motivasi belajar siswa.

Tabel 2. Rekapitulasi Angket Motivasi Belajar Matematika Siswa

\begin{tabular}{llc}
\hline No & \multicolumn{1}{c}{ Indikator } & \multicolumn{1}{c}{$\begin{array}{c}\text { Kategori } \\
(\%)\end{array}$} \\
\hline 1. & $\begin{array}{l}\text { Adanya hasrat dan } \\
\text { keinginan berhasil }\end{array}$ & 75,5 \\
\hline 2. & $\begin{array}{l}\text { Adanya dorongan dan } \\
\text { kebutuhan dalam belajar }\end{array}$ & 75,6 \\
\hline 3. & $\begin{array}{l}\text { Adanya harapan dan cita- } \\
\text { cita masa depan }\end{array}$ & 69,2 \\
\hline 4. & $\begin{array}{l}\text { Adanya penghargaan } \\
\text { dalam belajar }\end{array}$ & 77,1 \\
\hline 5. & $\begin{array}{l}\text { Adanya kegiatan yang } \\
\text { menarik dalam belajar }\end{array}$ & 72,8 \\
\hline \multicolumn{4}{c}{$\begin{array}{l}\text { Adanya lingkungan } \\
\text { belajar yang kondusif } \\
\text { sehingga memungkinkan } \\
\text { siswa dapat belajar } \\
\text { dengan baik }\end{array}$} & 78,4 \\
\hline \multicolumn{1}{c}{ Rata-rata } \\
\hline
\end{tabular}

\section{Keterampilan Komputer Siswa}

Hasil rekapitulasi nilai tes keterampilan komputer siswa kelas XI SMAN 1 Astanajapura masuk dalam kriteria "Baik", karena rata-rata skor total dipeoleh nilai presentase sebesar $73,06 \%$ berada pada interval 65 - 79 dengan kategori baik. Jadi dapat disimpulkan bahwa dengan penggunaan media pembelajaran berbasis komputer dapat meingkatkan keterampilan siswa dalam memanfaatkan komputer serta software-software yang ada di dalamnya.
Tabel 3. Rekapitulasi Nilai Keterampilan Komputer per-Indikator

\begin{tabular}{clc}
\hline No & \multicolumn{1}{c}{ Indikator } & \multicolumn{1}{c}{$\begin{array}{c}\text { Kategori } \\
(\%)\end{array}$} \\
\hline 1 & $\begin{array}{l}\text { Kemampuan dalam } \\
\text { mengidentifikasi menu- } \\
\text { menu dalam software } \\
\text { maple }\end{array}$ & 12,5625 \\
\hline 2 & $\begin{array}{l}\text { Kemampuan dalam } \\
\text { menjalankan software } \\
\text { maple }\end{array}$ & 8,375 \\
\hline & $\begin{array}{l}\text { Kemampuan menulis } \\
\text { dalam perintah maple } \\
\text { dan } \\
\text { menginterpretasikan } \\
\text { perintah maple }\end{array}$ & 39,094 \\
\hline 4 & Ketepatan jawaban & 13,03125 \\
\hline & \multicolumn{1}{c}{ Jumlah } \\
\hline
\end{tabular}

\section{B. Analisis Data}

Adapun langkah-langkah pengujian uji t dari angket penggunaan media pembelajaran berbasis komputer terhadap motivasi belajar siswa adalah sebagai berikut:

1. Menentukan Hipotesis

$\mathrm{H}_{0}$ : Penggunaan media pembelajaran berbasis komputer tidak berpengaruh terhadap motivasi belajar siswa

$\mathrm{H}_{\mathrm{a}}$ : Penggunaan media pembelajaran berbasis komputer berpengaruh terhadap motivasi belajar siswa

2. Kriteria Pengujian (berdasarkan signifikansi)

Jika nilai sig. $<0,05$ maka $\mathrm{H}_{0}$ ditolak, artinya penggunaan media pembelajaran berbasis komputer berpengaruh terhadap motivasi belajar siswa. 
Jika nilai sig. > 0,05 maka $\mathrm{H}_{0}$ diterima, artinya penggunaan media pembelajaran berbasis komputer tidak berpengaruh terhadap motivasi belajar siswa.

\section{Uji Hipotesis}

Tabel 4. Hipotesis Pengaruh Penggunaan Respon Siswa terhadap Media dan Motivasi Belajar Siswa

\begin{tabular}{|c|c|c|c|c|}
\hline \multicolumn{2}{|l|}{ Variabel } & Uji Hipotesis & Signifikansi & Keterangan \\
\hline $\begin{array}{l}\text { Penggunaan } \\
\text { Pembelajaran } \\
\text { Komputer Terhadap } \\
\text { Belajar siswa }\end{array}$ & $\begin{array}{r}\text { Media } \\
\text { Berbasis } \\
\text { Motivasi }\end{array}$ & Uji t & 0,000 & $\mathrm{H}_{0}$ ditolak \\
\hline
\end{tabular}

3. Membandingkan signifikansi

Sesuai dengan Tabel.4 dapat diketahui bahwa nilai signifikansi data angket penggunaan media pembelajaran berbasis komputer terhadap motivasi belajar siswa sebesar 0,000 karena $0,000<0,05$ maka $\mathrm{H}_{0}$ ditolak.

4. Kesimpulan

Nilai signifikansi yang dipeoleh dari angket penggunaan media pembelajaran berbasis komputer terhadap motivasi belajar siswa lebih kecil dari 0,05 yaitu 0,000 sehingga $\mathrm{H}_{0}$ ditolak, artinya penggunaan media pembelajaran berbasis komputer berpengaruh terhadap motivasi belajar siswa.

Tabel 5. Hipotesis Pengaruh Penggunaan Respon Siswa terhadap Media dan Keterampilan Komputer Siswa

\begin{tabular}{lrcccc}
\hline \multicolumn{2}{c}{ Variabel } & Uji Hipotesis & Signifikansi & Keterangan \\
\hline $\begin{array}{l}\text { Penggunaan Media } \\
\text { Komputer Tembelajaran } \\
\text { siswa }\end{array}$ & Berbasis & & & \\
\hline
\end{tabular}

Adapun langkah-langkah pengujian uji $\mathrm{t}$ dari angket penggunaan media pembelajaran berbasis komputer terhadap keterampilan komputer siswa adalah sebagai berikut:

1. Menentukan Hipotesis

$\mathrm{H}_{0}$ : Penggunaan media pembelajaran berbasis komputer tidak berpengaruh terhadap keterampilan komputer siswa
$\mathrm{H}_{\mathrm{a}}$ : Penggunaan media pembelajaran berbasis komputer berpengaruh terhadap keterampilan komputer siswa

2. Kriteria Pengujian (berdasarkan signifikansi)

Jika nilai sig. $<0,05$ maka $\mathrm{H}_{0}$ ditolak, artinya penggunaan media pembelajaran berbasis komputer berpengaruh terhadap keterampilan komputer siswa. Jika nilai sig. > 0,05 maka $\mathrm{H}_{0}$ diterima, artinya penggunaan 
media pembelajaran berbasis komputer tidak berpengaruh terhadap motivasi belajar siswa.

3. Membandingkan signifikansi

Sesuai dengan Tabel. IV.15 dapat diketahui bahwa nilai signifikansi data angket penggunaan media pembelajaran berbasis komputer terhadap motivasi belajar siswa sebesar 0,045 karena 0,045>0,05 maka $\mathrm{H}_{0}$ diterima.
4. Kesimpulan

Nilai signifikansi yang dipeoleh dari angket penggunaan media pembelajaran berbasis komputer terhadap motivasi belajar siswa lebih kecil dari 0,05 yaitu 0,045 sehingga $\mathrm{H}_{0}$ diterima, artinya penggunaan media pembelajaran berbasis komputer tidak berpengaruh terhadap keterampilan komputer siswa.

Tabel 6. Hipotesis Pengaruh Penggunaan Respon Siswa terhadap Media dan Motivasi Belajar Siswa

\begin{tabular}{lccc}
\hline \multicolumn{1}{c}{ Variabel } & Uji Hipotesis & Signifikansi & Keterangan \\
\hline $\begin{array}{l}\text { Pengaruh Antara Motivasi Belajar Terhadap } \\
\text { Keterampilan Komputer siswa }\end{array}$ & Uji t & 0,511 & $\mathrm{H}_{0}$ diterima \\
\hline
\end{tabular}

Adapun langkah-langkah pengujian uji t dari angket penggunaan media pembelajaran berbasis komputer terhadap keterampilan komputer siswa adalah sebagai berikut:

1. Menentukan Hipotesis

$\mathrm{H}_{0}$ : Motivasi belajar tidak berpengaruh terhadap keterampilan komputer siswa

$\mathrm{H}_{\mathrm{a}}$ : Motivasi belajar berpengaruh terhadap keterampilan komputer siswa

2. Kriteria Pengujian (berdasarkan signifikansi)

Jika nilai sig. $<0,05$ maka $\mathrm{H}_{0}$ ditolak, artinya motivasi belajar berpengaruh terhadap keterampilan komputer siswa.
Jika nilai sig. > 0,05 maka $\mathrm{H}_{0}$ diterima, artinya motivasi belajar tidak berpengaruh terhadap keterampilan komputer siswa.

3. Membandingkan signifikansi

Sesuai dengan Tabel. 6 dapat diketahui bahwa nilai signifikansi data angket penggunaan media pembelajaran berbasis komputer terhadap motivasi belajar siswa sebesar 0,511 karena 0,511>0,05 maka $\mathrm{H}_{0}$ diterima.

4. Kesimpulan

Nilai signifikansi yang dipeoleh dari angket penggunaan media pembelajaran berbasis komputer terhadap motivasi belajar siswa lebih 
kecil dari 0,05 yaitu 0,511 sehingga $\mathrm{H}_{0}$ diterima, artinya motivasi belajar tidak berpengaruh terhadap keterampilan komputer siswa.

\section{KESIMPULAN DAN SARAN}

\section{A. Kesimpulan}

Berdasarkan hasil penelitian mengenai pengaruh penggunaan media pembelajaran berbasis komputer terhadap motivasi belajar dan keterampilan komputer siswa, dapat disimpulkan bahwa:

1. Respon siswa terhadap pembelajaran matematika dengan menggunakan media komputer berbantuan software maple menunjukan kategori cukup baik dengan nilai prosentase $70,43 \%$.

2. Motivasi belajar siswa pada pembelajaran matematika dengan menggunakan media komputer menunjukan kategori cukup baik dengan nilai prosentase sebesar $74,77 \%$.

3. Hasil observasi nilai keterampilan komputer siswa dalam pembelajaran matematika dengan menggunakan media komputer menunjukan kategori baik dengan nilai prosentase sebesar $73,06 \%$.

4. Terdapat pengaruh yang signifikan antara penggunaan media pembelajaran berbasis komputer terhadap motivasi belajar dan keterampilan komputer siswa dengan nilai signifikansi sebesar 0,000 dan 0,045. Akan tetapi, tidak terdapat pengaruh yang signifikan antara motivasi belajar dan keterampilan komputer siswa

\section{B. Saran}

Berdasarkan penelitian yang tergambar dari bab sebelumnya, terdapat beberapa saran menyangkut penelitian yang telah penulis lakukan, yaitu:

1. Untuk guru, berdasarkan penelitian yang membuktikan bahwa terdapat pengaruh antara penggunaan media pembelajaran berbasis komputer terhadap motivasi siswa, diharapkan agar media komputer ini dijadikan salah satu alternatif media pembelajaran karena bisa membuat siswa lebih termotivasi dalam belajar matematika dan perlu mengadakan peningkatan tentang peran karir untuk pengembangkan minat dan bakat siswa sehingga siswa memiliki harapan dan cita-cita dimasa depan. Selain itu, dengan penggunaan media ini dapat meningkatkan keterampilan siswa dalam menggunakan komputer 
khususnya dalam menggunakan software-software matematika.

2. Untuk siswa, hendaknya selalu memanfaatkan waktu belajar dengan sebaik-baiknya dan dapat memanfatkan komputer sebagai salah satu media pembelajaran khususnya dalam pembelajaran

\section{DAFTAR PUSTAKA}

Arsyad, A. (2013). Media Pembelajaran. Jakarta: PT Rajagrafindo Persada.

Gufron, A., Darwan, \& Winarso, W. (2018). Penggunaan Bahan Ajar Berbasis Multimedia Interaktif terhadap Hasil Belajar Matematika Siswa. Inspiramatika, 4(2), 77-88.

Kustandi, C., \& Sujipto, B. (2016). Media Pembelajaran. Bogor: Penerbit Ghalia Indonesia. Nugroho, A. G. (2013). Eksperimentasi Penggunaan Media Komputer dalam Pembelajara Matematika pada Pokok Bahasan Logaritma ditinjau dari Motivasi Belajar Siswa Kelas X SMA Kota Surakarta. Banjarmasin. Pradnyawati, L. I. (2014). Pengaruh Strategi Blended Learning dalam Pembelajaran Kooperatif terhadap Motivasi Belajar Matematika ditinjau dari Gaya matematika. Karena motivasi belajar matematika siswa bisa tumbuh selain dari faktor dalam, juga muncul dari faktor luar yakni salah satunya dalam penggunaan komputer sebagai media pembelajaran.

\section{Belajar Siswa di SMP K 2}

Harapan. Singaraja.

Semadiartha, I. S. (2012). Pengembangan

Media Pembelajaran Berbasis

Komputer dengan Microsoft

Excel yang Berorientasi Teori

Van Hiele pada Bahasan

Trigonometri Kelas X SMA untuk

Meningkatkan Prestasi dan

Motivasi Belajar Matematika

Siswa. Artikel Tesis, 1-15.

Sugiyono. (2018). Metode Penelitian

Pendidikan. Bandung: Alvabeta.

Suharsaputra, U. (2012). Metode

Penelitian (Kualitatif, Kuantitatif,

dan Penelitian Tindakan Kelas).

Bandung: PT Refika Aditama.

Sukmadinata, N. S. (2016). Metode

Penelitian Pendidikan. Bandung:

PT Remaja Rosdakarya Offset.

Syahrir. (2012). Pengaruh Pembelajaran

Kooperatif Tipe Jigsaw dan

Teams Game Turnament (TGT)

terhadap Motivasi Belajar dan

Keterampilan Matematka Siswa 
SMP (Studi Eksperimen di SMP

Darul Hikmah Mataram).

Mataram.

Uno, H. (2008). Teori Motivasi dan

Pengukurannya. Jakarta: Bumi

Aksara.

Wanipah. (2014). Pengaruh Penggunaan

Media Pembelajaran Berbasis

Teknologi Informasi (TI) Software

Microsoft Mathematics terhadap

Motivasi Belajar Siswa pada

Pokok Bahasan Turunan Kelas XI

SMAN 1 Sliyeg. Cirebon.
Widyaningrum, Y. T. (2013). Pengaruh

Media Pembelajaran Geogebra

terhadap Motivasi dan Hasil

Belajar Siswa pada Materi Grafik

Fungsi Kuadrat di Kelas X SMA

Negeri 2 Yogyakarta Tahun

Pelajaran 2012/2013.

Yogyakarta.

Zahro, F. (2017). Perbandingan

Penerapan Metode Problem

Based Intruction dan Metode Two

Stay Two Stray Terhadap

Motivasi Belajar Matematika.

Cirebon. 